\title{
Tempo e espaço: pontos de contato em gêneros discursivos na Pedagogia da Alternância
}

\section{Time and Space: Contact Points in Discursive Genres in the Pedagogy of Alternation}

\author{
Cícero da Silva* \\ *Universidade Federal do Tocantins (UFT), Tocantinópolis, Tocantins / Brasil \\ cicolinas@yahoo.com.br
}

http:/ / orcid.org/0000-0001-6071-6711

\begin{abstract}
RESUMO: Neste artigo, objetiva-se analisar como o Tempo Escola e o Tempo Comunidade estão marcados/representados nos gêneros Caderno da Realidade e Caderno de Acompanhamento, dois instrumentos pedagógicos da Pedagogia da Alternância (PA). Trata-se de uma pesquisa de abordagem qualitativointerpretativista. O corpus é constituído por textos de seis exemplares do Caderno da Realidade e de três exemplares do Caderno de Acompanhamento, sendo utilizadas nas análises as categorias enunciativas na perspectiva benvenisteana. $\mathrm{O}$ estudo mostra que esses gêneros constituem lugar de grande relevância para registros de atividades e permitem ao estudante não só evidenciar suas experiências vivenciadas nos dois espaços e tempos formativos da PA, mas também expressar a reflexão, os saberes adquiridos, fazendo as devidas generalizações esperadas pela formação.
\end{abstract}

PALAVRAS-CHAVE: gêneros discursivos; escrita; enunciação; letramento; Pedagogia da Alternância.

ABSTRACT: In this paper, we aim to analyze how the School-Time and Community-Time are marked/represented in the genres Notebook of Reality and Monitoring Notebook, two pedagogical instruments of the Pedagogy of Alternation (PA). It is a research of qualitative-interpretative approach. The corpus is consisted of texts of six copies of the Notebook of Reality and three copies of the Monitoring Notebook, being used in the analysis the enunciative categories in the Benvenistean perspective. The study shows that these genres constitute a place of great relevance for records of activities and allow the student not only to evidence their experiences in the two spaces and formative times of PA, but also to express the reflection, the acquired knowledge, making the generalizations expected by the formation.

KEYWORDS: discursive genres; writing; enunciation; literacy; Pedagogy of Alternation. 


\section{Introdução}

Este trabalho ${ }^{1}$ integra nosso objeto de estudo para consecução da tese de doutoramento vinculada ao Programa de Pós-Graduação em Letras: Ensino de Língua e Literatura da Universidade Federal do Tocantins (PPGL/ UFT). É importante ressaltarmos que a pesquisa mais ampla, da qual esta representa uma parte, tem como objetivo principal analisar práticas e eventos de letramentos ${ }^{2}$ mediados pelos instrumentos pedagógicos da Pedagogia da Alternância (PA) em uma Escola Família Agrícola (EFA) brasileira (SILVA, 2018). Entretanto, neste artigo, o objetivo é verificar como os tempos Escola e Comunidade estão marcados/representados em instrumentos pedagógicos escritos da PA, como nos gêneros discursivos Caderno da Realidade (CR) e Caderno de Acompanhamento (CA).

O trabalho está situado no campo aplicado dos estudos da linguagem (MOITA LOPES, 2006) e, para investigar como tais práticas e eventos de letramentos são mobilizados/desenvolvidos na PA, especialmente durante a execução dos temas dos planos de estudo (PE) para elaboração dos textos do gênero CR, realizamos um estudo etnográfico na Escola Família Agrícola Zé de Deus (EFAZD), situada no município de Colinas do Tocantins, estado do Tocantins (SILVA, 2018). A pesquisa de campo foi desenvolvida em um período longitudinal em 2014 e contou com a participação direta e

\footnotetext{
${ }^{1}$ A pesquisa foi desenvolvida no âmbito do projeto intitulado "Caderno da Realidade na Pedagogia da Alternância: um instrumento pedagógico mediador do letramento" (PróReitoria de Pesquisa e Pós-Graduação da UFT no TO3\#001/2015) e contribui para as produções científicas do Grupo de Estudos e Pesquisas em Educação do Campo da UFT (Gepec/UFT) pelo Conselho Nacional de Desenvolvimento Científico e Tecnológico (CNPq). Registro aqui meus sinceros agradecimentos ao prof. dr. Adair Vieira Gonçalves (orientador), a prof ${ }^{a} \mathrm{dr}^{\mathrm{a}}$ Luiza Helena Oliveira da Silva (coorientadora) e ao prof. dr. Manoel Luiz Gonçalves Corrêa pelas contribuições à pesquisa.

${ }^{2}$ Para Street (2014), eventos e práticas de letramento não constituem o mesmo elemento, mas andam lado a lado. Isso porque “O conceito de 'práticas de letramento’ se coloca num nível mais alto de abstração e se refere igualmente ao comportamento e às conceitualizações sociais e culturais que conferem sentido aos usos da leitura e/ou da escrita. As práticas de letramento incorporam não só os 'eventos de letramento', como ocasiões empíricas às quais o letramento é essencial, mas também modelos populares desses eventos e as preconcepções ideológicas que os sustentam” (STREET, 2014, p. 18). Assim, de acordo com a esfera social de uso da linguagem, serão empreendidos diferentes eventos e práticas de letramento.
} 
indireta de nove monitores ${ }^{3}$ e 19 estudantes colaboradores da EFAZD na execução dos oito temas dos PE, na turma do $1^{\circ}$ ano do curso Técnico em Agropecuária Integrado ao Ensino Médio.

Conforme delineamos em nossa tese (SILVA, 2018), os registros da pesquisa (ampla) são: material audiovisual - como gravações das interações em sala de aula e de atividades desenvolvidas pelos alunos nas comunidades, diários de campo do pesquisador, documentos da escola-campo, registros fotográficos de atividades, espaços e objetos, além de textos de exemplares dos gêneros CR e CA produzidos pelos alunos colaboradores da turma focalizada.

Tendo em vista as categorias enunciativas de tempo e espaço estabelecidas por Benveniste (2006 [1974]), ressaltamos que o corpus deste artigo é constituído apenas por textos selecionados de seis exemplares do CR e de três exemplares do CA, produzidos por estudantes e monitores colaboradores da nossa pesquisa (SILVA, 2018) caracterizada anteriormente. Fizemos esse recorte, porque nosso propósito aqui é verificar (sob o ponto de vista da linguagem) como o Tempo Escola e o Tempo Comunidade da PA estão marcados/representados nos documentos analisados e buscar explicações para os fenômenos.

Assim, este artigo está estruturado em duas partes principais. A primeira traz a introdução e a perspectiva teórica que alicerça a pesquisa. $\mathrm{Na}$ segunda parte, apresentamos os dados da pesquisa, bem como as análises acerca dos textos dos gêneros CR e CA a partir das categorias enunciativas tempo e espaço, propostas por Benveniste (2006 [1974]). Por último, o trabalho apresenta as considerações finais com uma síntese dos principais resultados obtidos na pesquisa.

\footnotetext{
${ }^{3} \mathrm{Na}$ PA, monitor é a denominação que o professor recebe. Nesse contexto educativo, as atribuições de um monitor transcendem as atividades didático-pedagógicas recorrentes em sala de aula, já que esse profissional também assume a responsabilidade de acompanhar os estudantes tanto nas atividades escolares quanto em sua vida socioprofissional (SILVA, 2018). Por isso, adotaremos o vocábulo monitor para dirigirmo-nos ao professor.
} 


\section{A perspectiva teórico-metodológica e os dados da pesquisa}

\subsection{A Alternância e sua proposta formativa}

A PA surgiu na França em 1935, nas Maisons Familiales Rurales ${ }^{4}$ (Casas Familiares Rurais), e chegou ao Brasil em 1969. Essa Pedagogia é um sistema educativo caracterizado por uma organização do ensino própria, que valoriza os saberes, a cultura e a realidade socioprofissional do estudante camponês nos processos formativos (CALIARI, 2013; GIMONET, 2007; SILVA, 2011, 2018; SILVA; GONÇALVES, 2018). Para alcançar isso, as unidades de ensino que assumem a Alternância implementam diferentes atividades escolares articuladas a temáticas, às práticas cotidianas e à vida no meio rural, possibilitando agregar os conhecimentos acumulados pelos estudantes nas suas experiências concretas.

A formação por alternância congrega teoria e práxis, experiência e reflexão, desenvolvendo-se em tempos e espaços formativos diferentes que se alternam entre escola e família/propriedade, representados pelos: (i) Tempo Escola (TE): período de aulas no Centro de Formação/escola articulado entre estudo, pesquisa e propostas de intervenção; (ii) Tempo Comunidade (TC): período de vivência dos estudantes na propriedade/comunidade, pesquisa de estudo, realização de experimentos, trabalho coletivo, entre outras atividades (SILVA, 2011, 2018), além de estarem integrados com os instrumentos pedagógicos. ${ }^{5}$ Nessa perspectiva, a PA possibilita às crianças e aos jovens oriundos do meio agrícola aprender tanto por meio dos conhecimentos teóricos sistematizados na academia quantos dos saberes vinculados à realidade cotidiana do mundo camponês (GIMONET, 2007).

Embora ao longo de sua trajetória a PA tenha gestado e implementado nas experiências formativas nos CEFFA, diferentes instrumentos pedagógicos orais e escritos, como: (1) Colocação em comum, (2) Visita de estudo, (3) Intervenção externa, (4) Plano de Estudo, (5) Caderno da Realidade, (6) Caderno de Acompanhamento, (7) Projeto Profissional do Jovem, (8) Acompanhamento individual, (9) Visita à família, (10) Avaliação semanal (11), Atividade de retorno

\footnotetext{
${ }^{4}$ No Brasil, as Casas Familiares Rurais (CFR), as EFA e outras unidades de ensino que assumem a Alternância como modo de formação são conhecidas como Centros Familiares de Formação por Alternância (CEFFA).

${ }^{5}$ Para maiores detalhes a respeito dos instrumentos pedagógicos da PA, consultar Gimonet (2007) e Silva (2011, 2018).
} 
e (12) Cursos (COLINAS, 2015), nosso foco aqui são apenas dois dos instrumentos pedagógicos já caracterizados em nossas pesquisas anteriores, como os gêneros CR (SILVA, 2011, 2018; SILVA; MOREIRA, 2011; SILVA; ANDRADE; MOREIRA, 2015; SILVA; GONÇALVES, 2018) e CA (SILVA, 2018; SILVA; GONÇALVES, 2019).

\subsection{Os gêneros Caderno da Realidade e Caderno de Acompanhamento}

Levando em consideração as peculiaridades teórico-metodológicas da PA, a exemplo da denominação "instrumentos", entendemos que na área dos estudos da linguagem tal termo apresenta acepções diferentes.

Com base numa distinção entre artefato/ferramenta e instrumento, estabelecida por Rabardel (1995), Barros (2012, p. 63, grifo do autor) afirma que o artefato/ferramenta faz referência, de maneira neutra,

a toda coisa material, imaterial ou simbólica finalizada (no sentido que se destina a uma finalidade) de origem humana; já o instrumento somente passa a existir quando o artefato for "apropriado pelo e para o sujeito, com a construção de esquemas de utilização".

No entanto, conforme ressalta Rabardel (1995), embora a apropriação de um artefato, pelos sujeitos, configura-se numa gênese instrumental, ${ }^{6} \mathrm{o}$ artefato jamais pode ser apropriado na sua integralidade, mas sim em "partes", conforme o sujeito que dele se utilize, suas capacidades, o contexto sóciohistórico de utilização, entre outros aspectos, bem como o domínio da palavra.

Considerando que a palavra por si só é apenas unidade da língua, Bronckart (2009, p. 75) ressalta que a comunicação humana se efetiva por meio de texto, isto é, "toda unidade de produção de linguagem situada, acabada e autossuficiente (do ponto de vista da ação ou da comunicação)". Ainda de acordo com o autor, levando-se em conta o fato de que todo texto se agrupa a um conjunto de textos, é denominado de gênero de texto, e não gêneros do discurso. Em outras palavras, são os enunciados completos ou textos/gêneros.

${ }^{6}$ Conforme Schneuwly (2010, p. 124), gênese instrumental refere-se ao "processo de instrumentalização que provoca novos conhecimentos e saberes, que abre novas possibilidades de ações, que sustenta e orienta essas ações”. Por isso, os usuários da linguagem verbal necessitam agir para que possam se apropriar dos artefatos por meio da construção de esquemas de utilização. 
Diferentemente de Bronckart, em seus estudos, Bakhtin (2006, p. 262, grifo do autor) adota o termo gêneros do discurso, compreendidos como "tipos relativamente estáveis de enunciados". Enquanto "instrumentos" fundamentais das atividades de linguagem, os gêneros são construtos sócio-históricos situados em determinada esfera da comunicação humana. Na perspectiva dialógica, os gêneros são considerados "relativamente estáveis" porque "atendem as especificidades de comunicação de cada esfera quando se faz uso da linguagem" e é por meio "dos processos sociais ou de interação verbal que os gêneros são originados" (SILVA; ANDRADE; MOREIRA, 2015, p. 360). Vale lembrar que os gêneros do discurso são constituídos de três elementos básicos: conteúdo temático, estilo linguístico e construção composicional. Ademais, os gêneros, "materializados em textos, configuram a realidade das ações e das atividades de linguagem dos atores sociais, sendo frutos das interações humanas em determinado contexto social" (SILVA, 2018, p. 72). Portanto, assumimos neste estudo a concepção de gêneros do discurso na perspectiva bakhtiniana.

Apesar de o sistema educativo da PA completar cinco décadas de implantação no Brasil em 2019, trabalhos que abordam, especificamente, o instrumento pedagógico CR ainda são reduzidos, pois só identificamos a pesquisa de Rocha (2003) e estudos de nossa autoria em parceria com outros autores (SILVA, 2011; SILVA; MOREIRA, 2011; SILVA; ANDRADE; MOREIRA, 2015). Enquanto Rocha (2003) investiga a importância do CR para formação integral dos jovens de uma EFA do interior da Bahia, em Silva (2011) e Silva, Andrade e Moreira (2015) analisamos o processo de retextualização na construção do gênero CR em uma EFA situada no Tocantins. Já em nossa tese (SILVA, 2018), focalizamos a construção do CR a partir da implementação de oito diferentes temas geradores dos $\mathrm{PE}^{7}$ nas práticas de letramento de uma EFA. Portanto,

o Caderno da Realidade é um gênero que possibilita sistematizar e organizar os conhecimentos escolares em seus textos segundo a realidade das práticas educativas empreendidas nos CEFFA. Para ele existir, são necessárias diferentes atividades de linguagem empreendidas em diferentes esferas, como na escolar, na familiar e na comunidade. (SILVA, 2011, p. 70)

\footnotetext{
${ }^{7} \mathrm{Na}$ PA, PE são temas geradores facilitadores da interlocução de crianças e jovens em processo de formação com a família e a realidade socioprofissional da comunidade local (CALIARI, 2013; SILVA, 2018).
} 
O CR - enquanto instrumento didático-pedagógico escrito das unidades de ensino que assumem o sistema educativo da PA - é construído ao longo de um ano letivo concomitante com o estudo de oito temas geradores de PE diferentes vinculados às atividades do meio rural (SILVA, 2018). Nasceu da necessidade de sistematizar a pesquisa; nele o estudante registra suas reflexões e estudos aprofundados acerca dos temas dos PE. Trata-se, então, de um gênero que emerge de práticas sociais situadas em contextos de uso da linguagem (escola, família, comunidade), das quais crianças e jovens participam nas interações (orais e escritas) para produção de seus textos durante o TE e o TC.

Com base na concepção de plano geral, formulada por Bronckart (2009), Silva (2011) afirma que o CR incorpora e reelabora em sua estrutura composicional diferentes gêneros, ${ }^{8}$ como Pesquisa do PE, Colocação em comum, Sintese do PE: minha realidade, Intervenção externa, Visita de estudo e Conclusão $e$ avaliação do PE. Essas "seções" acumulam os registros das atividades executadas em diferentes etapas a respeito de cada um dos temas dos PE. Portanto, a finalidade do plano geral é apresentar na forma de um resumo como o seu conteúdo se organiza na discursividade do texto. Tendo em vista a especificidade do plano geral do CR, já que incorpora diferentes gêneros (SILVA; GONÇALVES, 2018), podemos afirmar que o CR apresenta características de um hipergênero (BONINI, 2011), e não de um suporte de gêneros (MARCUSCHI, 2008).

Por sua vez, o CA é o instrumento pedagógico que possibilita a comunicação entre a escola e a família no que diz respeito ao acompanhamento e orientação dos estudantes nas sessões do TE e do TC em uma unidade educativa que adota a PA (SILVA, 2018; SILVA; GONÇALVES, 2019). Assim, o CA

É um dos meios pelo qual a família e a Escola se relacionam na tarefa da formação do alternante. ${ }^{9}$ É uma oportunidade para a família e a Escola fazerem as observações sobre a aprendizagem dos educandos de forma planejada nos dois ambientes vividos e, simultaneamente, o

\footnotetext{
${ }^{8}$ Para maiores detalhes a respeito desses gêneros, consultar Silva $(2011,2018)$ e Silva, Andrade e Moreira (2015).

${ }^{9}$ Caliari (2013) utiliza o termo alternante em referência a crianças e jovens camponeses que estudam nas unidades educativas que praticam a Alternância.
} 
jovem planejar sua vida de trabalho, vivência e estudo e ao mesmo tempo analisar seu grau de desenvolvimento. (CALIARI, 2013, p. 425-426)

Dito de outra forma, o CA acumula registros decorrentes da atuação dos monitores e da família nas orientações dos estudantes nos diferentes espaços e tempos formativos da Alternância. Constitui-se num processo permanente, contínuo e colaborativo, uma vez que o referido Caderno, geralmente, é usado nos CEFFA desde a primeira até a última sessão de aula do ano letivo. É colaborativo, porque os registros dependem da participação dos monitores, dos estudantes e dos pais (SILVA; GONÇALVES, 2019). Cabe-nos ressaltar que, no caso particular da EFA/escola-campo em que realizamos nossa pesquisa, a partir do momento em que os pais matriculam seus filhos (menores) eles são orientados a verificar, registrar e comunicar questões relacionadas a atividades e ao processo ensino-aprendizagem dos filhos com os monitores da escola por meio do CA.

Advertimos o leitor que, com exceção de nosso estudo (SILVA; GONÇALVES, 2019), não localizamos na literatura nenhum outro estudo específico sobre o gênero CA na PA. Em nossa pesquisa, os exemplares desse gênero trazem dois tipos de seções individuais para registros: uma reservada para os registros (elaborados pelo monitor responsável pelo "acompanhamento individual" do aluno) das atividades do TE e outra para registros das atividades programadas na escola e realizadas na família/ comunidade pelo alternante durante o TC, cujo acompanhamento é de responsabilidade de um membro da família, preferencialmente o pai ou a mãe; ou outro responsável. Vale salientar que a quantidade dessas seções é produzida conforme o número de sessões do TE e do TC de um ano letivo.

Portanto, os gêneros CR e CA são importantes instrumentos didáticopedagógicos gestados nas experiências formativas das unidades de ensino que assumem o sistema educativo da PA.

\subsection{A enunciação e suas categorias}

Haja vista a gama de conteúdos presentes nos dados e registros dos gêneros CR e CA, nossas análises têm como base as categorias de tempo e espaço da enunciação propostas por Benveniste (2006 [1974]). Para o autor, "A enunciação é este colocar em funcionamento a língua por um ato individual de utilização." (BENVENISTE, 2006 [1974], p. 82). Em outras palavras, corresponde à apropriação da língua por um ato individual de 
dizer, o que não se traduz como uma perspectiva subjetivista da linguagem, tendo em vista que todo dizer instaura um outro, o "alocutário", sendo a intersubjetividade inerente à enunciação. Além disso, a enunciação é caracterizada como a "instância" de mediação entre a língua e a fala, sendo instância um conjunto de categorias linguísticas vinculadas ao ato de dizer.

Considerando a enunciação como "práxis", Fontanille defende que a enunciação "não é a origem primeira do discurso", pois:

Ela pressupõe algo diferente da atividade discursiva (o sistema da língua, mas também o conjunto de gêneros e tipos de discursos ou os repertórios e as enciclopédias de formas próprias a uma cultura). Ela supõe também uma história da práxis, dos usos, que seriam práxis anteriores assumidas por uma coletividade e estocadas na memória. (FONTANILLE, 2007, p. 272)

É nesse sentido que o dizer se articula com uma memória do dizer, que inclui as formas, as estruturas, mas também suas reconfigurações. Há o sistema e suas regras, mas também uma memória dos usos e, desse modo, o sujeito que se apropria da língua como locutor não apenas explora "o sistema em estoque, mas contribui para remodelá-lo e colocá-lo em devir" (FONTANILLE, 2007, p. 273). Nesse sentido, podemos dizer que o sistema não é uma totalidade imutável e definitiva, mas algo em movimento, alimentado pelos usos dos falantes. Esse uso permite mudanças, acréscimos, isto é, o sistema não existe independentemente dos sujeitos que dele fazem uso e, assim, "a perspectiva da práxis enunciativa é interativa" (FONTANILLE, 2007, p. 273, grifo do autor).

Benveniste (2006 [1974], p. 83) também ressalta que na enunciação devemos considerar, sucessivamente, "o próprio ato de dizer, as situações em que ele se realiza, os instrumentos de sua realidade". Dito de outra forma, a afirmação do autor refere-se às três categorias linguísticas mobilizadas quando tomamos a palavra: (i) pessoa (Eu e Tu): constituída no "ato de dizer"; (ii) tempo (Agora): momento ou "situações" em que tomo a palavra; (iii) espaço (Aqui): lugar daquele que fala. Portanto, o Eu, o Aqui e o Agora são os elementos que constituem as categorias da enunciação e estão presentes em todas as línguas. Em seu trabalho a respeito da enunciação, Fiorin (2016) destaca que esses três elementos indicam a pessoa, o espaço e o tempo da enunciação e dividem-se em dêiticos e anafóricos. Ainda segundo o autor, enquanto os dêiticos podem ser interpretados "com referência à 
situação de enunciação", os anafóricos, como elementos do enunciado, são "compreendidos em função de marcas temporais e espaciais instaladas no enunciado e de actantes do enunciado anteriormente mencionados" (FIORIN, 2016, p. 48). Fazendo uma relação com nosso objeto de estudo, entendemos que o tempo e o espaço são categorias de análise apropriadas para o estudo, como veremos na sequência.

A priori, exploramos nas análises tecidas sobre um conjunto de textos selecionados dos gêneros CR e CA a relação entre TE e TC de modo a observar, nos documentos analisados, em que medida esses tempos se misturam e em que medida eles se separam do ponto de vista da linguagem, buscando explicações para esses fenômenos. Isto é, buscamos verificar como os tempos e espaços estão marcados/representados nesses instrumentos pedagógicos escritos da PA.

\subsection{Critérios metodológicos para seleção e análise dos dados da pesquisa}

Cabe-nos destacar que o critério principal adotado para selecionar os textos para análise na pesquisa é que todos eles devem ser produzidos (por estudantes e/ou monitores) com base nas atividades desenvolvidas nos dois espaços e tempos formativos da Alternância, como é caso dos gêneros: ${ }^{10}$ (i) Pesquisa do PE; (ii) Colocação em comum; (iii) Síntese do PE: minha realidade; (iv) Intervenção externa; (v) Visita de estudo; e (vi) Conclusão e avaliação do PE, que integram o CR, bem como de outros do CA. Ademais, também levamos em consideração na seleção o fato de que esse conjunto de gêneros apresenta caracteres linguísticos que sinalizam a organização de diferentes espaços/tempos. Para tanto, realizamos, preliminarmente, um levantamento da ocorrência das categorias espaço e tempo nos textos desses gêneros que integram os dados da pesquisa.

Gostaríamos de registrar que, apesar de o termo "espaço" não ter sido empregado no título desta seção, o espaço é uma das categorias da enunciação e faz parte das nossas análises, tendo em vista sua centralidade na PA. Entendemos que as expressões "Tempo Escola" e "Tempo Comunidade" referem-se, dentro da PA, a dois espaços (concretos) formativos distintos: escola e família/comunidade/meio socioprofissional (SILVA, 2011, 2018).

\footnotetext{
${ }^{10}$ Para maiores detalhes a respeito desses gêneros, consultar Silva (2011, 2018), Silva, Andrade e Moreira (2015) e Silva e Gonçalves (2018).
} 
Tendo em vista as categorias tempo e espaço da enunciação formuladas por Benveniste (2006 [1974]), em nosso estudo não limitamos o enfoque sobre a realidade vivida pelos estudantes do sistema educativo da Alternância, num momento/espaço ou noutro momento/espaço. Referimo-nos aos tempos e espaços que são constituídos nos textos (dos gêneros CR e CA) analisados. Preliminarmente, depreendemos que esses tempos e espaços parecem estar mais ou menos misturados, evidenciando um contínuo das experiências de aprendizagem discursivizadas nos textos produzidos pelos estudantes. Diante disso, precisamos compreender como é ou se dá tal mistura/contínuo a partir da análise de elementos linguísticos que indiquem ambas as categorias nos enunciados dos textos desses gêneros.

Para tanto, nossas análises, sem desconsiderar as condições de produção mais imediatas (realidade concreta) e a própria historicidade da enunciação (CORRÊA, 2013), buscam observar indícios de caráter enunciativo, tendo em vista a atualização de recursos formais da língua que vão caracterizar o TE e o TC a fim de verificar como eles se articulam nos enunciados e os efeitos de sentido produzidos. Em outras palavras, tentaremos compreender como esses dados que ancoram o dizer no tempo e no espaço se apresentam nos textos analisados, considerando-se o emprego de elementos linguísticos que marcam essa relação (BENVENISTE, 2006 [1974]). Como a articulação da linguagem envolve e mobiliza as categorias tempo e espaço da enunciação, destacaremos a dimensão representativa da linguagem nessas duas categorias manifestadas nos textos dos gêneros focalizados na pesquisa. Vale ressaltar que estamos compreendendo texto, segundo Corrêa (2008, p. 76), como "registro do processo discursivo", ou seja, o texto (falado ou escrito) é um produto resultante de atividades linguístico-enunciativas.

\section{Tempo e espaço: pontos de contato em gêneros discursivos na Pedagogia da Alternância}

\subsection{Do espaço nos gêneros Caderno da Realidade e Caderno de Acom- panhamento}

O espaço, umas das três categorias enunciativas propostas por Benveniste (2006 [1974]), é estabelecido no texto a partir de um "aquil. Trata-se de uma categoria geralmente marcada por caracteres linguísticos 
específicos, a exemplo de pronome demonstrativo, advérbio de lugar ou adjunto adverbial de lugar.

Como observa Fiorin (2016), o espaço é uma categoria pouco explorada nos estudos de Benveniste (2005 [1966], 2006 [1974]). Por outro lado, a maioria das pesquisas desenvolvidas sobre esse tipo de categoria está situada nos estudos literários, "mas não sobre sua sintaxe (relação entre o espaço da enunciação e o do enunciado e suas projeções) e sim a respeito de sua semântica" (FIORIN, 2016, p. 229). Tal constatação mostra certa limitação dos trabalhos existentes a respeito da categoria espaço, assim como a escassez de pesquisas na área de estudos linguísticos.

Nos enunciados dos textos, o espaço pode apresentar-se implícito ou explícito. Embora o enunciador do discurso tenha como referência espacial o "aqui" [bic], não é preciso manifestar necessariamente o espaço no texto. Ao tratar dos principais elementos indicativos de espacialidade (este/esse: espaço da enunciação; aquele: espaço exterior ao espaço da enunciação), Fiorin (2016) propõe a seguinte reorganização: aqui: $1^{\mathrm{a}}$ pessoa; ai: $2^{\mathrm{a}}$ pessoa, ali: $3^{a}$ pessoa. Esses advérbios e demonstrativos são importantes indicadores linguísticos de espacialização dos objetos, uma vez que na construção dos enunciados é possível estabelecer uma marcação referida ou não referida do espaço no texto ao "aqui" da enunciação.

Além disso, sobretudo o "aqui”, possibilita na construção dos enunciados a debreagem enunciativa (marcação referida de espaço no texto com um "aqui") e a debreagem enunciva (marcação de espaço não referida ao "aqui" da enunciação). ${ }^{11}$ Ainda em relação a esta última, Fiorin (2016, p. 236, grifo do autor) esclarece que "A debreagem será enunciva, quando tivermos algures/albures, figurativizado ou não, instalado no enunciado".

Ao tratar brevemente da categoria espaço em sua obra, Benveniste (2006 [1974]) observa que,

\footnotetext{
${ }^{11}$ Conforme estudos da semiótica francesa relativos à enunciação sob a perspectiva benvenisteana, a projeção de pessoas, tempos e espaços no discurso produzem efeitos de subjetividade e aproximação (debreagem enunciativa) e afastamento e objetividade (debreagem enunciva). Ainda que essas categorizações possam ser importantes e pertinentes para os estudos na perspectiva enunciativa, não é nosso propósito explorá-las com mais profundidade neste artigo.
} 
Indicando os objetos, os demonstrativos organizam o espaço a partir de um ponto central, que é ego [eu], segundo categorias variáveis: o objeto está perto ou longe de mim ou de ti, ele é também orientado (defronte ou detrás de mim, no alto ou em baixo). O sistema de coordenadas espaciais se presta também para localizar todo objeto em qualquer campo que seja, uma vez que aquele que o organiza está ele-próprio designado como centro e ponto de referência. (BENVENISTE, 2006 [1974], p. 69-70, grifo nosso)

Considerando que do ponto de vista da enunciação benvenisteana a ordenação dos objetos pressupõe o estabelecimento de relações espaciais a partir de um ponto de referência “eu” (ego), geralmente os textos apresentam dois tipos de espaços, a saber: espaço tópico e espaço linguístico. Essas duas categorias são responsáveis pela ordenação ou estabelecimento da relação espacial das coisas.

Por sua vez, o espaço linguístico organiza-se "a partir do bic [aqui], ou seja, do lugar do ego [eu]. Todos os objetos são assim localizados, sem que tenha importância seu lugar no mundo, pois aquele que os situa se coloca como centro e ponto de referências da localização" (FIORIN, 2016, p. 233, grifo do autor). Nesse sentido, considerando que o espaço linguístico é caracterizado pela marcação referida de espaço no texto com um "aqui”, vale ressaltar que ele não é um espaço físico, mas é aquele no qual se dão os desdobramentos de cena enunciativa. Daí esse tipo de espaço pode trazer certos elementos linguísticos que o indiquem, como demonstrativos e certos advérbios de lugar.

Por outro lado, segundo Fiorin (2016, p. 233), o espaço tópicoé estabelecido nas línguas "seja como uma posição fixa em relação a um ponto de referências, seja como um movimento em relação a uma referência". Dito de outra forma, essa categoria de espaço pode ser determinada tanto em relação ao enunciador (ex. "à minha esquerda") quanto em relação a um elemento de referência localizado no enunciado (ex. "na frente da escola"). Diferentemente do que ocorre no espaço linguístico, esses exemplos reforçam que o espaço tópico instala-se nos textos com a marcação de espaço não referida ao "aqui" da enunciação. Portanto, essas duas categorias espaciais podem estar presentes em textos de diferentes gêneros, como é o caso do CR e do CA.

Para dar início às análises do conjunto de exemplares de textos selecionados dos dois cadernos, discorreremos sobre a organização do espaço no texto "Pedagogia da Alternância", que é uma espécie de 
"introdução" situada na primeira folha do gênero CR, da turma do $1^{\circ}$ ano do ensino médio de 2014 da EFAZD.

QUADRO 1 - Pedagogia da Alternância

\begin{tabular}{|c|} 
PEDAGOGIA DA ALTERNÂNCIA \\
Este modelo de Educação do Campo atende os(as) jovens \\
camponeses(as) e utiliza uma pedagogia específica - Pedagogia da Alternância. \\
Nessa Pedagogia o educando participa de atividades formais na sessão \\
escola durante uma semana, nos três períodos, em regime de internato. Na \\
semana seguinte sessão família/ comunidade, onde realiza as atividades \\
próprias do meio, trocas de experiências e associação do saber científico \\
com o popular, de forma que os dois ambientes favoreçam a construção do \\
conhecimento. \\
A Pedagogia da Alternância diferencia-se das demais pedagogias, pois \\
favorece que a família, a comunidade, as organizações populares e os órgãos \\
governamentais participem da formação integral do estudante. \\
(Colaborador Francisco, ${ }^{12}$ CR 8).
\end{tabular}

Como o texto do Quadro 1 está presente na primeira folha de todos os exemplares dos CR da turma colaboradora da nossa pesquisa na EFAZD, num primeiro olhar podemos pensar que se trata de um texto com conteúdo desalinhado da principal finalidade do gênero CR, que é ser o espaço apropriado para acumular os registros das diferentes etapas de atividades desenvolvidas (ao longo de um ano letivo) a respeito dos oito temas geradores dos PE.

No entanto, compreendemos que, devido ao fato de que a PA é ainda um espaço formativo pouco conhecido pelas pessoas em geral e que muitos alunos do $1^{\circ}$ ano são recém-chegadas à EFAZD, o texto (Quadro 1) ilustrado logo no início do CR possibilita que o enunciador apresente aos enunciatários (alunos, monitores e pais), brevemente, os princípios básicos e a forma de organização didático-pedagógica do sistema educativo da Alternância, assumindo o caráter de redundância ou de valorização da especificidade dessa modalidade de ensino. Além disso, ao tratar do desenvolvimento das atividades, estabelece-se uma ordenação dos espaços

\footnotetext{
${ }^{12}$ O texto do Quadro 1 foi elaborado pela coordenação pedagógica da EFAZD e está presente na primeira folha de todos os exemplares do CR da turma colaboradora de minha pesquisa em 2014 (SILVA, 2018)
} 
físicos formativos e também dos tempos que o enunciatário (estudante) deve participar na PA.

No texto do Quadro 1, como podemos observar, predominam sequências expositivas e argumentativas. O propósito desse texto é explicitar o que é a PA, assim como apresentar aos enunciatários a sucessão dos períodos (TE e TC) com que se dividem as etapas escolares nessa modalidade de ensino em uma EFA.

Além disso, o texto (Quadro 1) se torna importante, porque ele traz apontamentos sinalizados por elementos linguísticos tanto do ponto de vista da organização temporal quanto em relação ao espaço na PA. E o que vai predominar é o espaço tópico. Tendo em vista essa categoria de espaço, temos em "Este modelo de Educação do Campo [...]" (1 parágrafo) o pronome demonstrativo "este", que estabelece relação direta com o espaço marcado como o "aqui” da enunciação, voltando-se para o próprio texto. $\mathrm{O}$ emprego desse marcador espacial pelo enunciador indica algo que é o ponto de referência presente no enunciado, neste caso, o caderno específico para registros de atividades relativas à Pedagogia da Alternância.

Da mesma forma, a expressão "Nessa pedagogia [...]" (2 parágrafo) também faz uma referência ao sistema formativo da PA, que é o "lugar" onde a alternância é assumida e desenvolvida nas práticas didático-pedagógicas com os enunciatários (estudantes). Os dois exemplos apresentados dizem respeito ao espaço tópico, reforçando também que essa categoria de espaço aparece já no primeiro texto do CR. Portanto, o texto do Quadro 1, por ser introdutório, apresenta de maneira objetiva as coordenadas espaciais do(s) ambiente(s) de formação proposto(s) pela PA aos enunciatários. Apesar de constituir-se como uma apresentação e, como tal, explicitar aos enunciatários o caráter de especificidade do documento e as características da proposta educativa, observa-se a impessoalidade dos registros, dada pelo emprego da terceira pessoa. Os enunciatários não são expressamente convocados, não sendo referidos como um $t u / v o c \hat{e}$, mas como "educandos", "jovens camponeses", marcando o distanciamento e a objetividade do eles. O aqui, portanto, não é o espaço que converge os atores da enunciação, mas o espaço do texto mesmo, o lugar da práxis educativa diferenciada.

Com base na concepção de texto aqui assumida, situar os textos dos gêneros CR e CA como registros de atividades desenvolvidas em práticas de letramento exige, sobretudo, considerar que a enunciação é estabelecida em cada interação pela linguagem do aluno com diferentes participantes 
(monitor, pais, entre outros atores sociais), seja na escola ou na comunidade/ família/meio socioprofissional.

Por isso, para nossa análise, trazemos na sequência alguns exemplos ${ }^{13}$ de textos dos gêneros (i) Pesquisa do PE; (ii) Colocação em comum; (iii) Sintese do PE: minha realidade; (iv) Intervenção externa; (v) Visita de estudo; e (vi) Conclusão e avaliação do PE, que integram o CR, além de outros do CA. Esses gêneros da PA apresentam elementos linguísticos que marcam a organização do espaço. Para tanto, fizemos um levantamento da ocorrência da categoria espaço nos textos desses gêneros que integram os dados de nossa pesquisa. Na sequência, ilustramos três exemplos extraídos do CR, observando ser mais presente o espaço tópico:

(1) Esses alimentos são conseguidos em cidades viz̨inhas, no vizinho que possui uma hortinha e em supermercados. (Colaboradora Nelma, CR 11) (SILVA, 2018, p. 193)

(2) Abelhas africanizadas, os enxames são capturados na natureza. (Colaboradora Nelma, CR 11) (SILVA, 2018, p. 193)

(3) Lá se produz em alta escala, porque a produção tem o destino a comércios e feiras livres, a horta começou era pequena. (Colaboradora Ana, CR 14) (SILVA, 2018, p. 193)

Nos exemplos (1), (2) e (3), as locuções adverbiais de lugar "em cidades vizinhas", "no vizinho", "em supermercados", "na natureza”, "comércios" e "feiras livres" caracterizam o chamado espaço tópico, sugerindo referências figurativizadas a algures (a algum lugar). Isso porque tais expressões não indicam precisão do lugar. "Cidades vizinhas" pode ser qualquer cidade, pois não há um ponto de referência inscrito no enunciado. $O$ mesmo também ocorre com "em supermercados" e "comércios", já que não há um nome específico, mas apenas a referência a um tipo de estabelecimento comercial, o que aponta para a generalização e expansão das observações, característica dos enunciados do mundo da ciência que buscam a regularidade, o fenômeno e não o fato particular (CHEVALLARD, 2013). Por sua vez, "na natureza" vincula-se diretamente ao meio ambiente, quer seja a floresta, o cerrado,

${ }^{13}$ Todos os excertos dos gêneros CR e CA presentes neste artigo foram ilustrados, originalmente, em minha tese (SILVA, 2018). 
quer seja qualquer outro bioma. Embora esses exemplos designem o espaço tópico, não há uma referência explícita ao "aqui”" da enunciação.

Ademais, podemos dizer que em "esses alimentos" no exemplo (1) ocorre a dêixis espacial, pois refere-se aos alimentos que podem ser obtidos "em cidades vizinhas", "no vizinho" e/ou "em supermercados". Logo, o emprego do pronome "esses" é de suma importância no processo de referenciação e interpretação textual por parte do enunciatário.

É importante salientar que o espaço tópico é empregado, geralmente, quando se deseja precisar um espaço linguístico explicitamente manifestado ou não (FIORIN, 2016), como em "Lá" no exemplo (3). Nessa ocorrência, o termo "lá" faz referência explícita à "horta", que é o lugar visitado pelo enunciador (estudante) a fim de conhecer uma grande horta que produz verduras em escala comercial. Apesar de que o enunciador tenha conhecido o lugar (horta) e elaborado o relato focalizando a experiência vivenciada in loco, a organização do enunciado faz com que o "lá" aproxime o enunciador ao "aquil" da enunciação, e não ao lugar concreto (horta) referido no texto. O "lá" não é um lugar fixo no mundo natural, mas um lugar situado no espaço a partir da referência da enunciação, o do "aqui" do enunciador.

Por sua vez, o gênero Pesquisa do PE é constituído por um conjunto de questões/perguntas e respectivas respostas vinculadas ao tema gerador de um PE estudado, no qual predominam "sequências dialogais" (SILVA, 2011; SILVA; ANDRADE; MOREIRA, 2015). Tendo em vista essa peculiaridade, nossas análises revelaram que a categoria espaço tópico também predomina nos textos da Pesquisa do PE dos Cadernos da Realidade, como aparece nos exemplos (4 e 5) a seguir:

(4) É uma prática de colher frutos sem danificar a natureza e nem ter o trabalho de plantar e cuidar.

$\left.2^{\circ}\right)$ Quais são as principais atividades extrativistas da sua região?

$[\ldots]$

Para feiras livres.

$4^{\circ}$ ) Você acha que é vantajoso preservar 0 meio ambiente e através dessa preservação fazer uso dos produtos agroextrativista?

$[\ldots]$

Hoje em dia você tem que entra nas terras dos outros para pegar os frutos.

(Colaborador Leomar, CR 7) (SILVA, 2018, p. 194) 
(5) É comercializado na feira local. (Colaboradora Nelma, CR 11) (SILVA, 2018, p. 194)

Notamos também que, nos textos da Pesquisa do PE, há uma ocorrência frequente de elementos linguísticos que situam a exterioridade do espaço tradicional da escola. Com base nos exemplos (4) e (5), podemos citar as expressões: "a natureza", "sua região", "feiras livres", "o meio ambiente", "terras dos outros" e "na feira local". Considerando que, geralmente, a aplicação desse questionário ocorre fora do recinto escolar, essas expressões indicativas de espaço tópico ligam a espacialidade referenciada ao lar do estudante. Afinal, o enunciador vive no campo. Ao mesmo tempo, sinalizam os espaços de aprendizagem além do espaço tradicional da escola, que é uma proposta da PA.

Não muito diferente do questionário Pesquisa do PE, o espaço tópico é o mais predominante em outros textos de gêneros do CR como a Colocação em comum, a Sintese do PE: minha realidade, a Intervenção externa, a Visita de estudo e a Conclusão e avaliação do PE, embora sejam constituídos de relatos das experiências vivenciadas durante o desenvolvimento das atividades e reflexões a respeito dos temas geradores dos PE. Conforme nossa classificação realizada em pesquisas anteriores (SILVA, 2011; SILVA; ANDRADE; MOREIRA, 2015), esses gêneros são constituídos de sequências expositivas e narrativas.

(6) Na propriedade em que visitamos a floricultura, a mulher esclareceu para nós alunos sobre a floricultura. (Colaborador Francisco, CR 8) (SILVA, 2018, p. 195)

(7) As pessoas que foram visitadas costumam levar os produtos retirados da natureza para feiras da cidade. (Colaboradora Ana, CR 14) (SILVA, 2018, p. 195)

(8) Para desenvolver as atividades, na agricultura familiar é preciso união da família compromisso e trabalho, nas orientações para o cultivo da terra plantio e colheita. (Colaborador Leomar, CR 7) (SILVA, 2018, p. 195)

(9) O agricultor familiar pode alimentar o mundo sem agredir o meio ambiente. (Colaboradora Nelma, CR 11) (SILVA, 2018, p. 195) 
(10) Todas as semanas em que estamos na escola, nós falamos sobre "agricultura familiar". Esse assunto foi muito bom para nós todos, nós desenvolvemos muitas experiências novas. (Colaborador Eusébio, CR 12) (SILVA, 2018, p. 195)

(11) Na minha terceira semana de aula foi bem diferente na EFA. Tivemos palestras, fizemos visita na fazenda, foi divertido e bem produtiva. [...] Retornei à casa dos meus pais e continuei as atividades da Escola. Após concluir os trabalhos escolares, ajudei meus pais nos afazeres de casa. Fui para nossa chácara, cuidamos do plantio de maracujá, limpamos o pátio e colhemos feijão. (Colaborador Leomar, CA) (SILVA, 2018, p. 195)

Considerando que nos registros do $\mathrm{CR}$ as análises corroborem que prevalece o espaço tópico, é importante pontuar que os textos dos exemplos (6), (7), (8), (9), (10) e (11) falam do lugar da experiência, da práxis, da vivência dos estudantes (na condição agora de enunciadores), que, embora remetendo a um alhures generalizante, partem dos interesses imediatos e práticos desses atores humanos. Ainda que no exemplo (10) o enunciador faça referência ao espaço de ensino e aprendizagem "escola" (lugar da experiência acadêmica), o desenvolvimento do tema do PE Agricultura familiar proporcionou novos conhecimentos que estão vinculados diretamente ao lugar denominado campo, que é o espaço social em que os alunos (enunciadores) e suas famílias vivem. Além disso, em "esse assunto" presente no exemplo (10) ocorre o emprego do pronome demonstrativo esse em função anafórica, fazendo referência ao que acabou de ser dito, neste caso, ao tema "agricultura familiar".

Nos textos dos gêneros analisados, observamos certa regularidade de articulação do espaço tópico: escola X comunidade/família. Na maioria das ocorrências, os enunciadores (estudantes) sinalizam um olhar para o próprio lugar, que não é um espaço qualquer. É um lugar que tem relação direta com a vida dos estudantes, como exemplificado em (7), (8), (9), (10) e (11). Os enunciadores, por meio de seus textos, demonstram não estar preocupados apenas em adquirir um saber mais amplo, apenas aquilo que se adquiri na academia, pois buscam tanto um saber que transcenda o lugar (a realidade próxima, o aqui desses estudantes) quanto um saber ligado ao lugar escola, como aparece no exemplo (11) por meio das expressões sinalizadoras de lugar "na EFA", "na fazenda", "da Escola", "casa dos meus pais" e "nossa chácara". Quando o colaborador Leomar diz "casa dos meus pais" e "nossa 
chácara" no exemplo (11), o estudante cria uma contraposição entre o lugar da aprendizagem formal (EFA, escola) e o de um lugar mais subjetivo, um "aqui" pelo emprego dos pronomes possessivos (men, nossa), por meio dos quais enfatiza um lugar de um nós/nosso, o da família. Mais comuns nos textos, em geral, vemos então presentes nesse recorte mais expressões destacadas que fazem referência ao espaço tópico e aos caracteres que sinalizam o aqui/alhures da enunciação.

Portanto, considerando as análises delineadas a respeito da categoria espaço no conjunto de textos dos gêneros CR e CA, podemos reafirmar que não se manifesta uma preocupação dos enunciadores com o espaço da enunciação, mas sim com o espaço em que se situa a comunidade/ família, sua realidade socioprofissional. Daí ocorre uma predominância do espaço tópico nos enunciados. Ao mesmo tempo, a presença de elementos generalizantes relativos ao espaço aponta para o letramento acadêmico dos alunos, que conseguem enunciar não apenas as particularidades que envolvem a experiência imediata do aprendizado na escola e no campo, mas extrapolá-las para conhecimentos mais amplos que envolvem as práticas/ saberes implicados.

\subsection{O tempo construído nos gêneros Caderno da Realidade e Caderno de Acompanhamento}

Benveniste (2006 [1974]), ao abordar a "linguagem e a experiência humana", discorre sobre tempo físico, tempo crônico e tempo linguístico, diferenciando-os. Para o autor, o tempo físico do mundo é "infinito, linear, segmentável à vontade", além de ter "por correlato no homem uma duração infinitamente variável que cada indivíduo mede pelo grau de suas emoções e pelo ritmo de sua vida interior" (BENVENISTE, 2006 [1974], p. 71). Esse tempo, que em Benveniste aponta para a dimensão subjetiva da experiência da temporalidade, seria, para Fiorin (2016), o intervalo de tempo entre o início e o fim de determinado movimento, a exemplo do movimento de translação que a terra realiza para completar um ano.

Por outro lado, Benveniste (2006 [1974], p. 71) afirma que "Do tempo físico e de seu correlato psíquico, a duração interior, devemos distinguir com muito cuidado o tempo crônico, que é o tempo dos acontecimentos, que engloba também nossa própria vida enquanto sequência de acontecimentos”. Em outros termos, o tempo crônico é aquele em que podemos apontar determinado instante do tempo físico. Quando citamos, por exemplo, o mês, o ano ou a data 
de determinado acontecimento, estamos estabelecendo o marco temporal cronológico nos textos.

Além desse aspecto, Benveniste (2006 [1974], p. 71, grifo do autor) também ressalta que, "No tempo crônico, o que denominamos 'tempo' é a continuidade em que se dispõem em série estes blocos distintos que são os acontecimentos. Porque os acontecimentos não são o tempo, eles estão no tempo". Nessa perspectiva, o tempo representa a localização de determinado acontecimento, podendo este ser concomitante, anterior ou posterior a um presente, a um pretérito ou a um futuro estabelecido no momento da enunciação (FIORIN, 2016). Considerando que o tempo é uma construção da linguagem, ele pode ser sinalizado nos textos por meio, principalmente, dos tempos verbais, de advérbios e locuções adverbiais de tempo. Contudo, precisamos entender que

Uma coisa é situar um acontecimento no tempo crônico, outra coisa é inseri-lo no tempo da língua. É pela língua que se manifesta a experiência humana do tempo, e o tempo linguístico manifesta-se irredutível igualmente ao tempo crônico e ao tempo físico. (BENVENISTE, 2006 [1974], p. 74)

Ainda em relação às acepções de tempo crônico e tempo linguístico, Corrêa (2008) observa que as diferentes temporalidades podem ser estabelecidas como produtos de várias articulações envolvendo essas duas acepções. Daí, as atividades linguístico-enunciativas favorecem o estabelecimento, nos textos, de certos recortes de tempo que se vinculam ao tempo crônico ou ao tempo linguístico. Além disso, cabe-nos destacar que

O que o tempo linguístico tem de singular é o fato de estar organicamente ligado ao exercício da fala, o fato de se definir e de se organizar como função do discurso.

Este tempo tem seu centro - um centro ao mesmo tempo gerador e axial - no presente da instância da fala. (BENVENISTE, 2006 [1974], p. 74 , grifo do autor)

Considerando que nesse excerto Benveniste vincula tempo linguístico ao uso da língua (acontecimento linguístico) em contraposição à língua enquanto sistema e os textos analisados neste artigo sejam escritos, é oportuno lembrarmos que a enunciação constitui a instância de mediação entre a língua e a fala, o que reforça a presença da dimensão histórica por 
meio das marcas de temporalidade. Isso porque " $\mathrm{Na}$ qualidade de produto direto da enunciação, o tempo linguístico seria, portanto, um indicador da

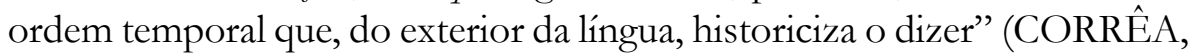
2008, p. 79-80, grifo do autor). Por último, devemos ressaltar que nem sempre as referências indicativas de tempo estão explícitas nos textos, cabendo-nos localizá-las nos enunciados.

Tendo em vista a gama de textos representados pela: (i) Pesquisa do PE; (ii) Colocação em comum; (iii) Sintese do PE: minha realidade; (iv) Intervenção externa; (v) Visita de estudo; e (vi) Conclusão e avaliação do PE, que constituem o $\mathrm{CR}$, assim como os textos do CA, veremos que há certa regularidade quanto à recorrência de elementos linguísticos que caracterizam a construção temporal nos enunciados. Com base em nossos recortes em relação à organização do tempo nesses gêneros e à recorrência dos tempos verbais nos textos, dividimos esta seção de análise em duas categorias: tempo presente epretérito e tempo futuro.

\subsubsection{Tempo presente e pretérito}

O tempo, haja vista as especificidades da PA, constitui um elemento importante da organização didático-pedagógica desse sistema educativo pensado sob a ótica da realidade camponesa. Para os camponeses, por exemplo, há o tempo ("certo") para preparar a terra para o cultivo, para plantar e colher; há também o tempo das festas, das manifestações culturais nas comunidades (SILVA, 2018). Portanto, esses exemplos referem-se ao tempo crônico, que é o tempo dos acontecimentos, o que difere do tempo linguistico.

$\mathrm{Na}$ perspectiva enunciativa, dependendo do tempo verbal manifesto (presente, pretérito ou futuro) nos textos, os verbos assumem papéis decisivos, principalmente em relação à ordenação ou marcação da categoria tempo linguístico. O presente, por exemplo, "marca uma coincidência entre o momento do acontecimento e o momento de referência presente.” (FIORIN, 2016, p. 132). Por isso, o autor ressalta que nesse tempo verbal deve haver uma tripla coincidência: momento da enunciação (ME), momento da referência (MR) e momento do acontecimento (MA).

No tocante ao tempo verbal marcado no texto do Quadro 1, no qual o enunciador aborda as principais características da PA, aparece nos enunciados o que Fiorin (2016) denomina presente omnitemporal. Esse tipo de presente expressa, ao enunciatário, a ideia de objetividade, de certeza, 
da coisa que é dada como verdadeira e que vai acontecer sempre. No texto (Quadro 1) o enunciador também enfatiza a concepção de alternância implementada na EFAZD, apontando a organização pedagógica e a sucessão dos períodos (TE e TC) ou etapas formativas do sistema educativo da PA quando diz:

(12) Nessa Pedagogia o educando participa de atividades formais na sessão escola durante uma semana, nos três períodos, em regime de internato. $\mathrm{Na}$ semana seguinte sessão família/ comunidade, onde realiza as atividades próprias do meio, trocas de experiências e associação do saber científico com o popular. (Colaborador Francisco, CR 8) (SILVA, 2018, p. 191)

A “sessão escola" corresponde ao TE e equivale, na EFAZD, a uma semana de aula (em período integral) em que os enunciatários (estudantes) do texto do Quadro 1 participam. Por sua vez, a "sessão família/ comunidade" é igual ao TC, sendo o período constituído de uma semana em que os enunciatários permanecem em suas comunidades/famílias (também conhecido como meio socioprofissional) e desenvolvem pesquisas e atividades elencadas para o período. Podemos afirmar que esses enunciados estão sinalizados por presente durativo, em que o verbo "participa" acena para um presente maior que o presente pontual do agora da enunciação ("na sessão escola durante uma semana") e uma posterioridade apresentada como um contínuo com referência ao agora pontual da enunciação ("na semana seguinte sessão família/comunidade", "realiza"), caracterizando o modo de constituição da formação como uma continuidade que se estende entre duas temporalidades sucessivas. Além disso, cabe-nos ressaltar que tais expressões são empregadas para sancionar a temporalidade das "etapas" formativas inerentes ao sistema educativo da PA desenvolvidas em uma EFA.

Assim, ao analisarmos os verbos que aparecem em cada um dos parágrafos do texto do Quadro 1, como "atende" e "utiliza” (1 parágrafo); "participa", "realiza" e "favoreçam" (2 parágrafo); e "diferencia-se", "favorece" e "participem" (3 parágrafo), notamos que o presente é o tempo verbal que predomina nesse exemplar de texto, como modo de caracterizar a maneira de ser desse sistema específico de formação. Da mesma forma, o presente é o tempo que aparece em outros textos do gênero CR, como ilustram os exemplos a seguir, comuns nos gêneros acadêmicos: 
(13) $\mathrm{Na}$ época de florada as abelhas produ₹em mais mel, que são os meses de maio, junho, setembro e novembro. Quando os apicultores saem para capturar as abelhas para que eles não sejam atacados deve-se usar macacão, luvas e botas de borracha. (Colaborador Leomar, CR 7) (SILVA, 2018, p. 200)

(14) Quando o piscicultor não tem um conhecimento ideal éum desperdício. Porque os peixes podem ser maltratados e isso vai levar eles até a morte. (Colaborador Hélio, CR 4) (SILVA, 2018, p. 200)

(15) $[\ldots]$ em minha realidade, o solo de onde vivo é arenoso. Eé muito ruim [...]. Existem pouquíssimos locais em que a terra éboa para plantação. Mas quando queremos mesmo que as plantas peguem, utilizamos adubo orgânico [...]. (Colaboradora Nelma, CR 11) (SILVA, 2018, p. 200)

(16) As pessoas que estão nesta área [há] alguns anos acham vantajoso preservar o meio ambiente [...]. (Colaboradora Ana, CR 14) (SILVA, 2018, p. 200)

Como podemos observar, o exemplo (13) traz os elementos adverbias "na época da florada" e "quando", cuja função é servir de momento de referência dos fatos relatados. À expressão "na época de florada" estão vinculados os verbos "produzem" e "são", ambos no tempo presente. Não diferente, o verbo "saem", também no presente, liga-se diretamente a "quando". Diante disso, podemos afirmar que o momento de referência época em que as abelhas produzem mel e o momento de capturar as abelhas - desses exemplos coincide com o momento dos acontecimentos: produzir, ser, sair, ao mesmo tempo em que guardam a relação de concomitância com o presente da enunciação. Simultaneamente, esse presente se mostra durativo, mais extenso que o presente pontual, contribuindo para o efeito de generalização do saber apresentado.

Um pouco semelhante ao exemplo (13), o exemplo (14) inicia-se com o advérbio "quando", que é o momento de referência dos fatos narrados. Os verbos "tem" e "é", no presente, estabelecem relação direta com o momento de referência e estende-se até o momento da enunciação. Já o verbo "podem" (também no presente), associado a "vai levar" (futuro), indica um momento incerto, que pode ser o tempo futuro, uma vez que "podem" sugere dúvida, incerteza.

Por outro lado, um pouco diferente dos exemplos (13) e (14), os verbos do exemplo (15) “em minha realidade, o solo de onde vivo éarenoso. 
E é muito ruim [...]. Existem pouquíssimos locais em que a terra é boa para plantação" indicam o que Fiorin (2016) classifica como presente omnitemporal. Como ressalta o autor, essa forma verbal é muito utilizada pela ciência, pela religião e pela sabedoria popular, cujo propósito principal é enunciar "verdades eternas". Nesse sentido, podemos dizer que os verbos "é" e "existem" asseguram ao enunciatário uma verdade absoluta (do ponto de vista popular) ao definir a "realidade" do solo descrita pelo enunciador (estudante). Além disso, reafirmando uma das características do presente omnitemporal, o momento de referência desse enunciado do exemplo (15) é na verdade um sempre não explícito.

No último exemplo (16) desse conjunto de textos, o momento de referência está implícito, embora apareça a expressão "[há] alguns anos" indicativa de um tempo remoto, distante da realidade linguístico-enunciativa construída no texto. Os verbos "estão" e "acham" também apresentam a característica do presente omnitemporal, pois descrevem no texto a visão ou pensamento "imutável" das "pessoas" em relação ao tema abordado (Agroextrativismo). Portanto, com base em Fiorin (2016), podemos afirmar que o momento de referência nesse exemplo (16) é ilimitado e coincide com o momento do acontecimento.

Além do presente, nosso levantamento em textos do CR e do CA mostra que também é recorrente o pretérito nesses gêneros. Em contraposição ao tempo presente, o pretérito "marca uma relação de anterioridade entre o momento do acontecimento e o momento de referência presente" (FIORIN, 2016, p. 135), como mostra o exemplo a seguir:

(17) Sexta-feira, dia 22 fizemos a colocação em comum com o professor Virgulino. A primeira pergunta foi se as famílias consomem verduras frequentemente. Dois alunos disseram que, às vezes, o resto da sala confirmaram que sempre, pois é um hábito saudável. (Colaboradora Nelma, CR 11) (SILVA, 2018, p. 202)

Conforme podemos observar no enunciado desse exemplo (17), o momento de referência ao agora da enunciação nesse texto é a etapa de desenvolvimento do PE denominada "Colocação em comum", que ocorreu numa certa "sexta-feira, dia 22". Para enfatizar que o momento dos acontecimentos sinaliza concomitância em relação ao momento de referência pretérito ("sexta-feira, dia 22"), os enunciados trazem os verbos "fizemos", "foi", "disseram" e "confirmaram" (os quais estão no pretérito). 
Com base em Fiorin (2016), podemos afirmar que esses verbos indicam uma descontinuidade do momento de referência, isto é, referem-se a uma ação acabada, que se finalizou na tal "sexta-feira, dia 22".

Em relação à frequência do tempo pretérito nos Cadernos analisados, a pesquisa mostrou que há maior predominância desse tipo de tempo naqueles textos de gêneros constituídos de sequências expositivas e narrativas, ${ }^{14}$ a exemplo da Colocação em comum, Sintese do PE: minha realidade, Intervenção externa, $V$ isita de estudo e a Conclusão e avaliação do PE. Nesses textos, os enunciatários (estudantes) expõem ou relatam suas experiências de aprendizagem envolvendo execução de diferentes atividades vinculadas aos estudos dos temas do PE:

(18) A visita foi feita na horta do setor Santa Rosa no dia 05/09/14 em Colinas-TO e não tinha a presença de nenhum dos proprietários, mas tinha um trabalhador o senhor José Filho que foi nosso palestrante. (Colaboradora Ana, CR 14) (SILVA, 2018, p. 202)

(19) Durante esta semana aprendi muito pois tivemos aulas teóricas e práticas. Nas aulas práticas aprendemos a importância da sementeira e como devemos montar uma. Em relação a convivência com os colegas e monitores correu tudo dentro da normalidade. (Colaborador Francisco, CA) (SILVA, 2018, p. 202)

(20) Bom, hoje visitamos uma pequena floricultura em Colinas para nós aprofundarmos mais no conteúdo. Uma senhora que nos apresentou seu jardim explicon várias dúvidas da turma [...]. (Colaboradora Nelma, CR 11) (SILVA, 2018, p. 202)

\footnotetext{
${ }^{14}$ Ainda que sejam recorrentes nos gêneros CR e CA elementos linguísticos que nos permitam tomá-los como gêneros constituídos - sobretudo, de sequências textuais que caracterizem "escritas do Eu", por narrarem ou descreverem acontecimentos, implementação de atividade (na escola e/ou na comunidade), situações de aprendizagens, como mostram os exemplos (17), (18), (19), (20) e (21) -, eles não são, a princípio, autobiográficos (LEJEUNE, 2008). Portanto, por entendermos que tais gêneros não podem, por excelência, ser classificados como memórias, autobiografia ou mesmo diário, neste trabalho não aprofundaremos a discussão sobre "narrativa retrospectiva".
} 
(21) Para mim, esta pesquisa foi muito boa, nossa visita a uma horta foi ótima para despertar novos conhecimentos. A turma toda interagiu, os professores nos ajudaram bastante.

Aqui mesmo na EFA comentamos sobre o assunto todos os dias [...]. Gostei muito da pesquisa. (Colaboradora Nelma, CR 11) (SILVA, 2018, p. 202)

No exemplo (18), aparece a data “05/09/14”. Trata-se de um elemento preciso e indicativo do tempo cronológico em que os fatos relatados pelo enunciador ocorreram, porém desvinculados do agora da enunciação. Esse marco temporal cronológico ou momento de referência - 05/09/14 - está ligado diretamente a um plano anterior ao momento da fala, o qual é referenciado por alguns verbos no pretérito: "foi feita", "tinha" e "foi". Simultaneamente, esses elementos linguísticos fazem referência explícita e pontual a uma anterioridade (a um passado), isto é, ao assunto e fatos abordados no texto. A presença desses usos linguísticos que remetem ao tempo cronológico serve para ancorar o texto produzindo efeito de verdade e objetividade, sendo ainda previstos pelos gêneros em questão.

Embora o exemplo (19) seja introduzido com a expressão "Durante esta semana" sinalizadora do tempo dos acontecimentos e "esta semana" remeta a um presente, na verdade a presença dos verbos "aprendi", "tivemos", "aprendemos" e "correu" no pretérito revela uma anterioridade ao tempo linguístico. As formas verbais "aprendi” e "tivemos", na construção do enunciado, revelam a presença de dêiticos indicativos de $1^{\mathrm{a}}$ e $3^{\mathrm{a}}$ pessoas do discurso opondo-se ao tempo da enunciação.

Por outro lado, apesar de o enunciador do texto (20) ter escolhido o advérbio "hoje" para balizar o momento ou instância inicial em que os fatos relatados no texto ocorreram, "hoje" não marca de maneira precisa nem explícita o tempo dos acontecimentos no sentido da ancoragem temporal prevista pelo gênero, mas apenas o momento da enunciação. Além disso, considerando que os verbos "visitamos", "apresentou" e "explicou" estão marcados no tempo pretérito, eles indicam um tempo não preciso, ligado ao "hoje" (visita a uma floricultura) dos fatos descritos e anterior ao agora, momento da enunciação. Portanto, o advérbio "hoje" inserido no enunciado evidencia dois tempos, um antes - o das atividades relatadas - e o agora da enunciação. 
No exemplo (21), as expressões "esta pesquisa" e "nossa visita" indicam ao enunciatário os momentos de referência dos fatos descritos: pesquisa e visita. São importantes porque, assim como ocorre nos exemplos (18), (19) e (20), tais expressões situam os fatos num momento diferente do tempo da enunciação. Por sua vez, os verbos "foi", "interagiu", "ajudaram", "comentamos" e "gostei" no pretérito instituem a situação relatada em um plano acabado, revelando uma anterioridade ao tempo linguístico.

Por outro lado, o texto (22), que integra o CR do colaborador da pesquisa Eusébio, expõe um pouco das transformações do saber do próprio enunciador (estudante) na Pedagogia da Alternância:

(22) Durante esses tempos de estudos aprendi coisas que ainda não tinha reconhecimentos, às vezes podemos observar algumas desvantagens, mais a aplicação do PE foi bem aplicado e claramente precioso pra aqueles que tem o interesse de trabalhar em jardinagem.

As vezes a gente pensa que sabe tudo sobre alguma coisa e ainda não sabemos nada, por exemplo tem pessoas que trabalha com a jardinagem e ainda não fez um curso para ter bons conhecimentos naquela área.

Mais isso é normal, muitas das pessoas quando já está trabalhando na área é que passa a ter um reconhecimento melhor.

Todos nós podemos ter um jardim em nossa propriedade, porque é simples e fácil para manusear, e como já tivemos algumas aulas e visitas teremos mais conhecimento. Lembrando que a jardinagem é muito importante para o nosso habitat e comunidades. (Colaborador Eusébio, CR 12) (SILVA, 2018, p. 203-204)

Nos enunciados do texto (22), cujo foco é o tema do PE Jardinagem e paisagismo, o enunciador (estudante) ressalta a aquisição de um saber proporcionado pela formação na PA. Aqui se revela um ator social que muda sua compreensão sobre um fato da realidade e expressa essa transformação, claro, a partir das atividades desenvolvidas a respeito do tema do PE focalizado no texto.

Quando o enunciador afirma: "Durante esses tempos de estudos aprendi coisas que ainda não tinha reconhecimentos [...]", depreendemos que ele pontua com o verbo "aprendi" no tempo pretérito um "antes" ou passado negativado de seus saberes acerca da jardinagem. Em contraposição a isso, afirma no $4^{\circ}$ parágrafo do texto (22) que "Todos nós podemos ter 
um jardim em nossa propriedade, porque é simples e fácil para manusear, e como já tivemos algumas aulas e visitas teremos mais conhecimento". Ao dizer que todos nós (estudantes, previstos como enunciadores) podemos possuir um jardim “porque é simples e fácil para manusear" e destacar que com as aulas e visitas obteve mais conhecimento, ressalta o agora e o futuro positivados. São entrelaçamentos de tempos que marcam a trajetória das práticas de letramento das quais esse e outros colaboradores da pesquisa participam na PA.

Como os estudantes são avaliados por esses textos, eles devem ali dar provas da aprendizagem, evidenciando o que de novo foi adquirido e como isso será usado no meio socioprofissional. Portanto, o texto (22) permitenos identificarmos o antes (negativado) e o agora (positivado) na vida do enunciador (estudante). São transformações na vida dos estudantes que são decorrentes do desenvolvimento das atividades em diferentes tempos e espaços formativos da alternância.

Portanto, tendo em vista que no início desta seção enfatizamos que os textos dos gêneros aqui analisados são constituídos em sua maioria por relatos e predominam sequências expositivas e narrativas, os vários exemplos ilustrados anteriormente corroboram uma forte marcação do tempo pretérito. Não se trata de uma escolha de caráter individual e aleatória, porque não é indiferente às coerções genéricas, tendo ligação estreita com a própria organização/constituição textual dos gêneros. Entendemos que essa característica da marcação de temporalidade se vincula ao letramento dos enunciadores (estudantes), além de ser demonstração de que os estudantes foram capazes de produzir os textos conforme os propósitos das atividades indicadas para o desenvolvimento no TE e TC.

\subsubsection{Tempo futuro}

Nas análises desta pesquisa, ficou evidente que o tempo futuro também é empregado com certa frequência, dependendo dos propósitos do texto. Segundo Fiorin (2016, p. 136), “o futuro do presente indica uma posterioridade do momento do acontecimento em relação a um momento de referência presente". A título de ilustração, segue o exemplo (23):

(23) E quando retornar a minha chácara colocarei em prática tudo que aprendi com meus professores. (Colaborador Leomar, CR 7) (SILVA, 2018, p. 205) 
Tendo em vista o momento de referência presente nesse excerto, o verbo "colocarei" indica uma posterioridade ao tempo referido em "quando retornar a minha chácara”, que é o momento do acontecimento. Além desse exemplo (23), registramos a seguir algumas outras ocorrências ou marcas indicativas de futuro nos textos da pesquisa:

(24) Às vezes o que parece perca de tempo hoje pode ser o que vai faz̧er toda diferença amanhã. Refazer um texto é querer melhorar e isso é reconhecer que podemos. (Texto da Monitora Vanessa. Colaborador Marcos, CA) (SILVA, 2018, p. 205)

(25) Para que você tenha melhor aproveitamento dos estudos realizados é necessário que você se disponha a fazer as atividades propostas na sessão escola e quando estiver em casa tire um tempo todo dia para rever os conteúdos estudados. Sucesso. (Texto da Monitora Vanessa. Colaborador Marcos, CA) (SILVA, 2018, p. 205)

Nesses dois exemplos (24 e 25), a escolha de marcadores linguísticos indicativos de temporalidade no texto pelo enunciador (neste caso, é o monitor/agente de letramento) aponta para dois momentos distintos articulados por um plano de referência ao assunto e posterior ao momento da fala: presente (hoje) x futuro (amanhã). Para enfatizar o caráter persuasivo do enunciado, são usadas locuções verbais como "pode ser", "vai fazer", "é querer melhorar" e "é reconhecer". Destacamos "vai fazer" e "é querer melhorar", que são locuções verbais indicativas de um tempo futuro em relação ao momento da fala. As instâncias da enunciação mobilizadas no texto (24) permitem-nos afirmarmos que há uma expectativa forte do enunciador (monitor) acerca do letramento na vida dos enunciatários (estudantes), cuja preocupação reforça a necessidade de maior envolvimento/compromisso do próprio estudante com sua formação que se desenvolve no "presente", mas que aponta para o "futuro".

Desse modo, no exemplo (25), o enunciador (monitor) convoca o enunciatário (estudante) para o comprometimento com relação a sua formação, apontando para um devir: "Para que tenha melhor aproveitamento dos estudos realizados é necessário que você se disponha a fazer as atividades propostas". Novamente, aparecem os verbos "tenha", "é" e "disponha a fazer" com o intuito de convencer o enunciatário (estudante) a refletir sobre o agora e o futuro. Por último, é importante pontuar que essa relação 
linguística estabelecida entre o enunciador e o enunciatário nos textos do CA supõe, do ponto de vista do discurso, que um não existe sem o outro. Por isso mesmo, a mensagem do monitor demonstra em ambos os exemplos (24 e 25) uma tentativa de lembrar o estudante quanto à importância de "rever os conteúdos estudados" em casa, no TC. Ademais, a intervenção não se dá em termos de correção textual gramatical ou mesmo técnica em relação aos conteúdos expostos, mas aponta para um diálogo que tem em vista uma interação mais comprometida de um ponto de vista com o outro em sentido mais amplo.

Além disso, tendo em vista a forma de manifestação do tempo linguístico na organização do texto (25), o emprego do termo "sucesso" chama a atenção por apontar para um tempo futuro. O sucesso aparecerá para o estudante, mas depende do engajamento deste nas práticas de letramento das quais participa (na escola e fora dela). Há condição pré-estabelecida para o sucesso (o empenho do enunciatário), mas também uma precisão quanto ao que fazer para chegar lá, numa relação argumentativa de causa versus consequência.

\section{Considerações finais}

Com essas análises, buscamos mostrar que as funções dos gêneros CR e CA na Alternância ultrapassam a dimensão escolarizante de verificação do emprego gramatical da língua e da circunscrição aos limites do que o gênero compreende do ponto de vista estrutural. Interessaria mais a reflexão sobre as aprendizagens em processo, o modo de retomar as experiências relatando-as dentro do que se compreende como pertinente a cada gênero, atualizado pela singularidade dos gestos de escritura, a historicidade do dizer (CORRÊEA, 2013) e nas negociações frente aos enunciatários implícitos na medida em que, considerando a dimensão enunciativa, todo texto pressupõe um outro.

Nesse sentido, os estudantes, na condição de enunciadores, fazem escolhas que se circunscrevem às coerções do gênero, mas que também atuam do ponto de vista argumentativo-persuasivo com vistas a serem bem acolhidos pelo monitor (professor avaliador). Além disso, os textos do CR e do CA são lugar de evidenciar as experiências nos dois espaços e tempos de aprendizagem propostos pelo sistema educativo da Pedagogia da Alternância, mas também de expressar a reflexão, o saber adquirido, fazendo as devidas generalizações esperadas pela formação. 
Ademais, embora o enfoque deste artigo seja categorias enunciativas como tempo e espaço, propostas por Benveniste (2006 [1974]), a pesquisa também revela que os gêneros CR e CA constituem lugar de grande relevância para formação dos estudantes, uma vez que os registros de ambos os gêneros emergem de práticas e eventos de letramento situados em contextos de uso da linguagem (escola, família, comunidade), das quais os estudantes participam nas interações (orais e escritas) para produção de seus textos (SILVA, 2018; SILVA; GONÇALVES, 2018).

Ainda com base nas análises, podemos destacar que a marcação de espaço e tempo nos textos desses gêneros pode estar vinculada ao(s) letramento(s) dos estudantes (neste caso, enunciadores), além de ser demonstração de que tais estudantes foram capazes de produzir os textos conforme os propósitos das atividades dirigidas para o desenvolvimento nos TE e TC. Portanto, são formas de sistematização, imediatamente implicadas com o letramento. Simultaneamente, concretiza-se nos textos dos cadernos o modo de funcionamento da formação na Alternância.

\section{Referências}

BAKHTIN, M. Os gêneros do discurso. In: BAKHTIN, M. Estética da criação verbal. 4. ed. São Paulo: Martins Fontes, 2006. p. 261-335.

BARROS, E. M. D. Gestos de ensinar e de aprender gêneros textuais: a sequência didática como instrumento de mediação. 2012. 358f. Tese (Doutorado em Estudos da Linguagem) - Universidade Estadual de Londrina, Londrina, 2012.

BENVENISTE, E. Problemas de linguistica geral I. 5. ed. Campinas: Pontes Editores, 2005 [1966]. 387p.

BENVENISTE, E. Problemas de linguística geral II. 2. ed. Campinas: Pontes Editores, 2006 [1974]. 294p.

BONINI, A. Mídia/suporte e hipergênero: os gêneros textuais e suas relações. Revista Brasileira de Linguística Aplicada, Belo Horizonte, v. 11, n. 3, p. 679-704, 2011. Doi: http://dx.doi.org/10.1590/S1984-63982011000300005

BRONCKART, J.-P. Atividade de linguagem, textos e discursos: por um interacionismo sociodiscursivo. 2. ed. São Paulo: Educ, 2009.353p.

CALIARI, R. A presença da família camponesa na escola família agrícola: o caso de Olivânia. 2013. 563f. Tese (Doutorado em Educação) - Universidade Federal do Espírito Santo, Vitória, 2013. 
CHEVALLARD, Y. Sobre a teoria da transposição didática: algumas considerações introdutórias. Revista de Educação, Ciências e Matemática, Rio de Janeiro, v. 3, n. 2, p. 1-14, maio/ago. 2013.

COLINAS. Projeto Pedagógico da Escola Municipal Família Agrícola Zé de Deus de Colinas do Tocantins-TO. Colinas do Tocantins: s/n, 2015.

CORRÊA, M. L. G. Arranjos referenciais de tempo em textos de pré-universitários: letramento e oralidade. Gragoatá, Niterói, n. 25, p. 75-93, 2008.

CORRÊA, M. L. G. Bases teóricas para o ensino da escrita. Linguagem em (Dis) curso, Tubarão, v. 13, n. 3, p. 481-513, 2013. Doi: https:/ / doi.org/10.1590/S151876322013000300003

FIORIN, J. L. As astúcias da enunciação: as categorias de pessoa, espaço e tempo. 3. ed. São Paulo: Ática, 2016. 288p.

FONTANILLE, J. Semiótica do discurso. São Paulo: Contexto, 2007. 288p.

GIMONET, J.-C. Praticar e compreender a Pedagogia da Alternância dos CEFFAs. Petrópolis: Vozes; Paris: AIMFR, 2007. 167p.

LEJEUNE, P. Opacto autobiográfico: de Rousseau à internet. Belo Horizonte: Editora UFMG, 2008. 404p.

MARCUSCHI, L. A. Produção textual, análise de gêneros e compreensão. São Paulo: Parábola, 2008. 296p.

MOITA LOPES, L. P. Uma Linguística Aplicada mestiça e ideológica: interrogando o campo como linguista aplicado. In: MOITA LOPES, L. P. (org.). Por uma Linguística Aplicada indisciplinar. São Paulo: Parábola Editorial, 2006. p. 13-44.

RABARDEL, P. Les Hommes et les technologies: une approche cognitive des instruments contemporains. Paris: Armand Colin, 1995. Disponível em: https:// bit.ly/2FfU4O6. Acesso em: 26 abr. 2018.

ROCHA, I. X. O. Uma reflexão sobre a formação integral nas EFAs: contributos do Caderno da Realidade nesse processo na EFA de Riacho de Santana-Bahia. 2003. 242f. Dissertação (Mestrado em Ciências da Educação) - Universidade Nova de Lisboa; Universidade François Rebelais de Tours, Lisboa; Tours, 2003.

SCHNEUWLY, B. Palavra e ficcionalização: um caminho para o ensino da linguagem oral. In: SCHNEUWLY, B.; DOLZ, J. (org.). Gêneros orais e escritos na escola. Campinas: Mercado de Letras, 2010. p. 109-124.

SILVA, C. Pedagogia da Alternância: um estudo do gênero caderno da realidade com foco na retextualização. 2011. 149f. Dissertação (Mestrado em Letras: Ensino de Língua e Literatura) - Universidade Federal do Tocantins, Araguaína, 2011. 
SILVA, C.; MOREIRA, F. Caderno da Realidade enquanto gênero discursivo: conceituação, constituição e práticas sociais. In: SIMPÓSIO INTERNACIONAL DE ESTUDOS DE GÊNEROS TEXTUAIS, 6., 2011, Natal. Anais [...] Natal: UFRN, 2011. p. 1-15. Disponível em: https://bit.ly/2wWMcxf. Acesso em: 20 dez. 2018.

SILVA, C.; ANDRADE, K. S.; MOREIRA, F. A retextualização no gênero Caderno da Realidade na Pedagogia da Alternância. Acta Scientiarum. Language and Culture, Maringá, v. 37, n. 4, p. 359-369, 2015. Doi: http://dx.doi.org/10.4025/ actascilangcult.v37i4.25050

SILVA, C. Pedagogia da Alternância: práticas de letramentos em uma Escola Família Agrícola brasileira. 2018. 232f. Tese (Doutorado em Letras: Ensino de Língua e Literatura) - Universidade Federal do Tocantins, Araguaína, 2018.

SILVA, C.; GONÇALVES, A. V. A etnografia e suas contribuições para o desenvolvimento de uma pesquisa no contexto de ensino da Pedagogia da Alternância. Trabalhos em Linguística Aplicada, Campinas, v. 57, n. 1, p. 551-578, 2018. Doi: http://dx.doi.org/10.1590/010318138651040333151

SILVA, C.; GONÇALVES, A. V. O gênero Caderno de Acompanhamento na Pedagogia da Alternância: espaço de diálogo entre família e escola. Fórum Linguístico, Florianópolis, v. 16, n. 2, 2019. No prelo.

STREET, B. Letramentos sociais: abordagens críticas do letramento no desenvolvimento, na etnografia e na educação. Tradução de Marcos Bagno. São Paulo: Parábola Editorial, 2014. 240p.

Data de submissão: 04/01/2019. Data de aprovação: 12/06/2019. 